[Agr. Biol. Chem., Vol. 32, No. 4, p. 479 483, 1968]

\title{
Studies on the Myrosinase in Mustard Seed
}

\author{
Part III. On the Effects of Neutral Salts* \\ By Isao Tsuruo** and Tadao Hata \\ Research Institute for Food Science, Kyoto University, Kyoto \\ **Technical Research Laboratory, Asahi Chemical Industry Co., Ltd., \\ Itabashi-ku, Tokyo \\ Received October 9, 1967
}

\begin{abstract}
A characteristic effect of inorganic neutral salts on myrosinase was discovered. The salts containing monovalent anions had a remarkable inhibitory effect on the ascorbateactivated enzyme, but little on the non-activated enzyme. Such an effect was elucidated to be due to the anion. For the ascorbate-activated enzyme, a linear relation was obtained by plotting the logarithms of the enzymatic activity against the square roots of the ionic strength of the salts. Therefore, the effect of monovalent anions is ascribable to the ionic strength of the solvent. The $K m$ values of the activated and non-activated enzyme were increased by the presence of the monovalent anion.
\end{abstract}

Concerning the inhibitory effect of various reagents on mustard myrosinase, some experiments have been carried out by Reese et al. ${ }^{11}$ and by Nagashima and Uchiyama. ${ }^{21}$ Many kinds of organic and inorganic compounds known as enzyme inhibitors have been shown to possess an inhibitory effect on the myrosinase.

The present authors ${ }^{3 /}$ have tried to detect the inhibitors, mainly among $\mathrm{SH}$-inhibitors, which have different effects on the ascorbateactivated and non-activated state of the enzyme, but these inhibitors have not been discovered.

Recently, the present authors found the characteristic inhibitory effect of various

* Parts of this work were presented at the Annual Meeting of the Japanese Biochemical Society, October 1965, Fukuoka and the Annual Meeting of Agricultural Society of Japan, April 1966, Kyoto.

1) E. T. Reese, R. C. Clapp and M. Mandels, Arch. Biochem. Biophys., 75, 228 (1958).

2) Z. Nagashima and M. Uchiyama, Nippon Nogeikagaku Kaishi, 33, 980 (1959).

3) I. Tsuruo and T. Hata, Agr. Biol. Chem., 31, 27 (1967).

4) Z. Nagashima and M. Uchiyama, Nippon Nogeikagaku Kaishi, 33, 478 (1959). anions on the enzyme. The results are given as follows.

\section{MATERIALS AND METHODS}

Substrate. Sinigrin was prepared from yellow mustard seed ${ }^{45}$ ) and used as the substrate of the myrosinase.

Enzyme preparation. The same myrosinase solution prepared from yellow mustard seed as described previously ${ }^{3}$ was used throughout the following experiments.

Inorganic salts. All inorganic salts used in the following experiments were of analytical grade.

Enzyme assay. The reaction mixture contained $2.5 \mu$ moles of sinigrin and $1 \mu$ mole of 2-mercaptoethanol in a total volume of $1 \mathrm{ml}$. The enzymatic activities were measured by titration of the liberated sulfate using a recording $\mathrm{pH}$-stat as described previously.3,5, The activation of the enzyme was accomplished by addition of $1 / \mu$ mole of L-ascorbate per $1 \mathrm{ml}$ of the reaction mixture. The reactions were carried out at pH 5.2 and $37^{\circ} \mathrm{C}$.

Enzyme assay by determination of liberated glucose. The enzymatic activities were separately measured by determining the liberated glucose ac-

5) 1. Tsuruo, M. Yoshida and T. Hata, Agr. Biol. Chem., 31, 18 (1967). 
cording to Summer's dinitrosalicylic acid method ${ }^{61}$ with the modification previously described.5) In these cases, the enzymatic reactions were conducted in the system described above, containing $0.2 \mathrm{M}$ acetate buffer, $\mathrm{pH}$ 5.2. The measurement of the enzymatic activities described here was applied to obtain the results given in Fig. 6.

\section{RESULTS}

The effects of various neutral salts on the enzyme were tested keeping the ionic strength at 0.5 in the reaction mixture. The results are shown in Table I. Varying ranges of influence were observed with the respective salts.

Figures 1 and 2 show the relations between the salt concentrations and their effects on the enzymatic activity. Two distinguishable types of effects were observed, namely, the effect of salts containing monovalent anions and the effect of a divalent one. Both types of anions had relatively small effects on the enzyme without ascorbate (though the inhibitory effect was observed at higher concentrations, as shown in Fig. 1) but, with $10^{-3} \mathrm{M}$ ascorbate,

TABLE I. EFFECT OF VARIOUS INORganic SALTS ON MYROSINASE

\begin{tabular}{|c|c|c|}
\hline \multirow{2}{*}{ Salts } & \multicolumn{2}{|c|}{ Ascorbate } \\
\hline & Not added & $10^{-3} \mathrm{M}$ \\
\hline $\mathrm{NaCl}$ & 100 & 100 \\
\hline $\mathrm{KCl}$ & 104 & 89.2 \\
\hline $\mathrm{NH}_{4} \mathrm{Cl}$ & 110 & 108 \\
\hline $\mathrm{CaCl}_{2}$ & 94.8 & 114 \\
\hline $\mathrm{BaCl}_{2}$ & 110 & 151 \\
\hline $\mathrm{MgCl}_{2}$ & 112 & 151 \\
\hline $\mathrm{Na}_{2} \mathrm{SO}_{4}$ & 129 & 192 \\
\hline $\mathrm{K}_{2} \mathrm{SO}_{4}$ & 134 & 193 \\
\hline$\left(\mathrm{NH}_{4}\right)_{2} \mathrm{SO}_{4}$ & 147 & 204 \\
\hline $\mathrm{NaNO}_{3}$ & $: 25$ & 35.2 \\
\hline $\mathrm{NaBr}$ & 118 & 75.8 \\
\hline $\mathrm{K}^{-} \mathrm{YO}_{3}$ & 128 & 52.3 \\
\hline
\end{tabular}

Enzymatic reactions were carried out at $\mathrm{pH} 5.2$ and $37^{\circ} \mathrm{C}$. Ionic strength of each salt was 0.5 . Enzymatic activity in the presence of $0.05 \mathrm{M} \mathrm{NaCl}$ was taken as 100

6) J. B. Sumner, J. Biol. Chem., 65, 393 (1925). their effects became obviously distinguishable Against the ascorbate-activated myrosinase, the effects of salts containing monovalent anions were the activation at concentrations lower than $0.05 \mathrm{~m}$, but, at higher concentrations, the effects of them changed to remarkable inhibition on the enzyme inversely. For example, in the case of sodium chloride, the activities of the ascorbate-activated enzyme were approximately 23,9 and 3.5 times of the nonactivated enzyme at $0.05,0.5$ and $3.0 \mathrm{M}$, respectively.

On the contrary, the effect of the salts containing the divalent anion was non-characteristic. Little change was observed on the effect by alteration of the cation of the salts. This conclusion is derived from the results on the effect of chloride salts as shown in Figs. 1 and 2.

The effect of monovalent anions was not influenced by the $\mathrm{pH}$ of the reaction mixture. Figure 3 illustrates the effect of sodium chloride at $\mathrm{pH} 5.2$ in comparison to $\mathrm{pH} 7.0$. Very similar curves occurred regardless of the $\mathrm{pH}$ in the presence or absence of ascorbate.

In Fig. 4, the data presented in Fig. 1 are plotted as common logarithms of the enzymatic activities against the square roots of the

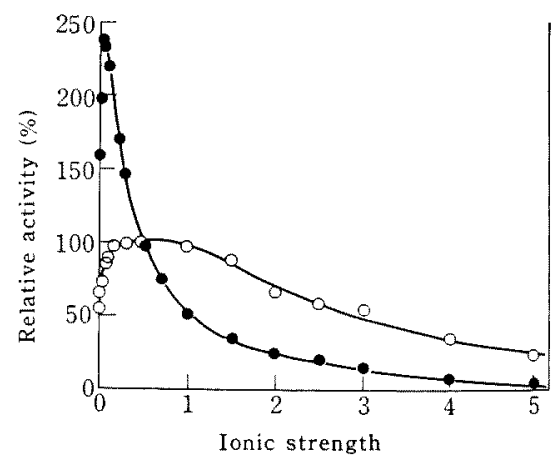

FIG. 1. Effect of $\mathrm{NaCl}$ on Myrosinase.

Enzymatic reactions were carried out with( and without $(\bigcirc) 10^{-3} \mathrm{M}$ ascorbate at $\mathrm{pH} 5.2$ and $37^{\circ} \mathrm{C}$.

When the ionic strength of $\mathrm{NaCl}$ was 0.5 , the activities were taken as $100 \%$. 

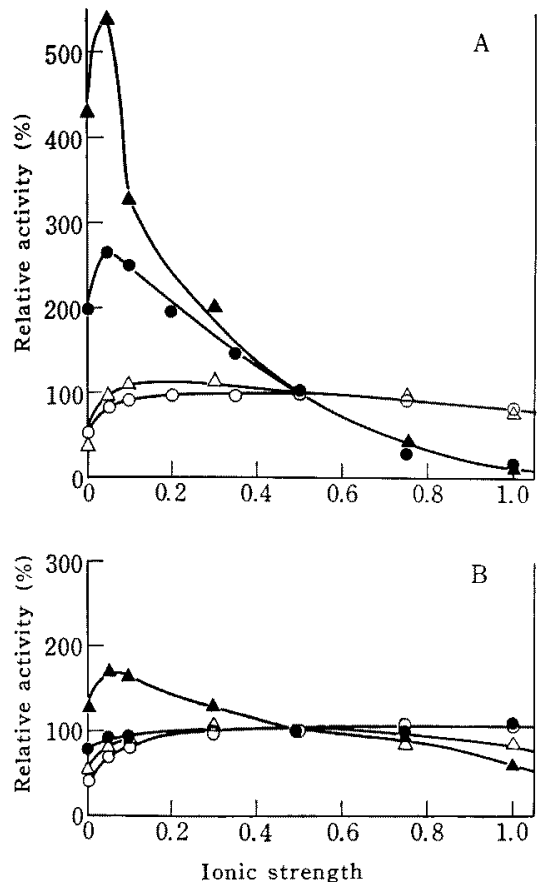

FIG. 2. Effect of Neutral Salts on Myrosinase.

Enzymatic reactions were carried out at $\mathrm{pH} 5.2$ and $37^{\circ} \mathrm{C}$.

A: Data for $\mathrm{KCl}$ with (O) and without (O) $10^{-3} \mathrm{M}$ ascorbate and for $\mathrm{NaNO}_{3}$ with (A) and without $(\triangle) 10^{-3} \mathrm{M}$ ascorbate.

B: Data for $\mathrm{Na}_{2} \mathrm{SO}_{4}$ with (O) and without (O) $10^{-3} \mathrm{M}$ ascorbate and for $\mathrm{CaCl}_{2}$ with (A) and without $(\triangle) 10^{-3} \mathrm{M}$ ascorbate.

Activities of each salt at ionic strength 0.5 were taken as 100 .

ionic strength of sodium chloride. In the presence of $10^{-3} \mathrm{~m}$ ascorbate, these data showed a linear relationship.

The kinetic constants of the myrosinase at various concentrations of sodium chloride were determined. The results are shown in Table II. Both in the presence and absence of $10^{-3} \mathrm{M}$ ascorbate, the $K m$ value of the enzyme for the substrate increased with an increment in the concentration of sodium chloride. In regard to the $K m$ value for ascorbate, it was not affected by sodium chloride (Fig. 5).

The experimental results mentioned above

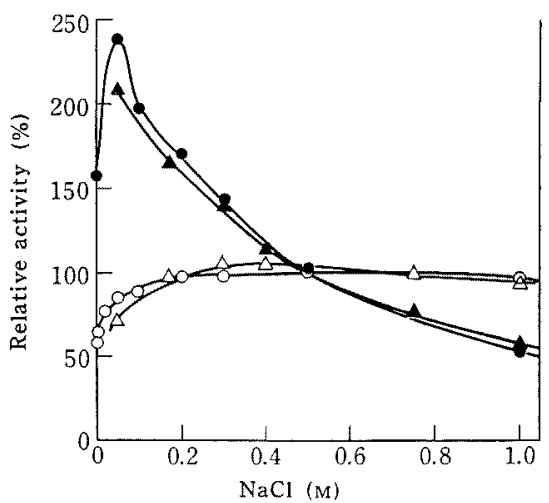

Fig. 3. Effect of $\mathrm{NaCl}$ on Myrosinase at $\mathrm{pH} 5.2$ and 7.0 .

Enzymatic reactions were carried out at $37^{\circ} \mathrm{C}$.

Data at $\mathrm{pH} 5.2$ with $(0)$ and without $(\mathrm{O}) 10^{-3} \mathrm{M}$ ascorbate and at $\mathrm{pH} 7.0$ with (A) and without

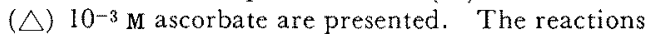
at $\mathrm{pH} 7.0$ were carried out under $\mathrm{N}_{2}$ gas stream. Activities at $0.5 \mathrm{M} \mathrm{NaCl}$ were taken as 100 .

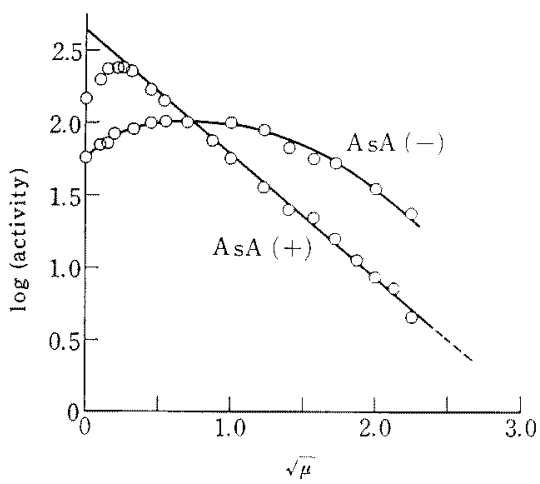

FIG. 4. Relation of the Ionic Strength of $\mathrm{NaCl}$ to Myrosinase Activity.

$\mu=$ Ionic strength.

Data presented in Fig. 1 are plotted.

AsA (-): Ascorbate was not added.

AsA (+): $10^{-3} \mathrm{M}$ Ascorbate was added.

were obtained by titration of the liberated sulfate. Similar results were obtained by measurements of the liberated glucose. Figure 6 shows the data given by this method. Also remarkable inhibition by sodium chloride was observed in the presence of $10^{-3} \mathrm{M}$ ascorbate, 
TABLE II. EFFECT OF NaCl ON KinETIC Constants of Myrosinase

\begin{tabular}{|c|c|c|c|c|}
\hline \multirow{3}{*}{$\underset{(\mathrm{M})}{\mathrm{NaCl}}$} & \multicolumn{3}{|c|}{ Ascorbate } & \\
\hline & Not & idded & \multicolumn{2}{|c|}{$10^{-3} \mathrm{M}$} \\
\hline & $\begin{array}{c}V_{\mathrm{max}} \\
\text { (/moles/ } \\
\mathrm{min} / \mathrm{ml})\end{array}$ & $\begin{array}{c}K m \\
\left(10^{-4} \mathrm{M}\right)\end{array}$ & $\begin{array}{c}V \max \\
(\mu \text { moles } \\
\mathrm{min} / \mathrm{ml})\end{array}$ & $\begin{array}{c}K m \\
\left(10^{-4} \mathrm{M}\right)\end{array}$ \\
\hline 0.05 & 2.74 & 0.94 & 87.6 & 2.6 \\
\hline 0.5 & 3.48 & 1.8 & 52.2 & 9.2 \\
\hline 2.5 & 2.33 & 6.4 & 15.9 & 27.8 \\
\hline
\end{tabular}

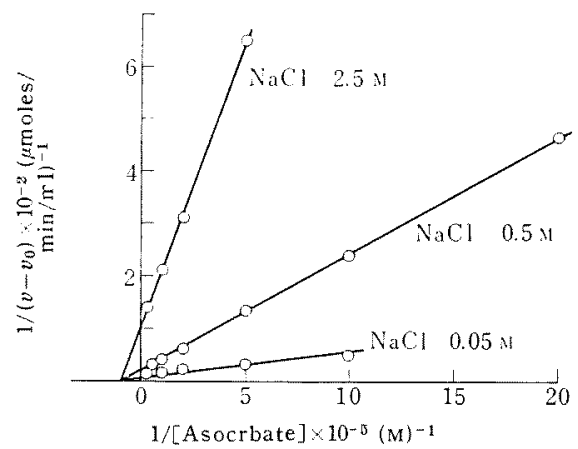

FrG. 5. Efrect of $\mathrm{NaCl}$ on the $K m$ Value for Ascorbate.

Enzymatic reactions were carried out at $\mathrm{pH} 5.2$ and $37^{\circ} \mathrm{C}$.

$v_{0}$ : Velocity in the absence of ascorbate. $\left.{ }^{3}\right)$

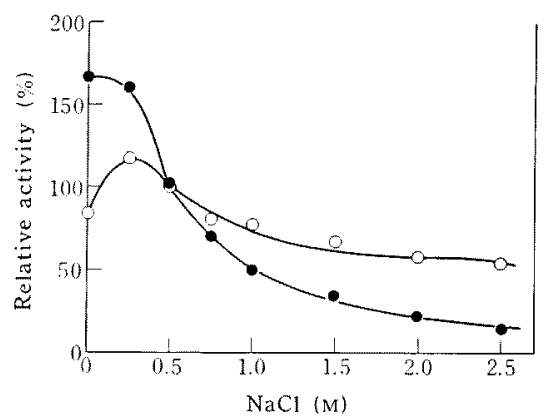

FIG. 6. Effect of $\mathrm{NaCl}$ on Myrosinase Activity.

The same kind of experiment with Fig. 1 is presented except for an addition of $0.2 \mathrm{M}$ acetate in the reaction mixture. The reactions were carried out at $37^{\circ} \mathrm{C}$ and $\mathrm{pH} 5.2$ with (O) and without (O) $10^{-3} \mathrm{M}$ ascorbate.

The enzymatic activities were determined by colorimetry of liberated glucose.

Activities at $0.5 \mathrm{M} \mathrm{NaCl}$ were taken as 100 . and the inhibitory effect in the absence of ascorbate was weaker than its presence.

\section{DISCUSSION}

In the previous paper, ${ }^{3 \prime}$ the present authors reported that reagents which inhibit myrosinase selectively in the activated state were not detected among the common enzyme inhibitors. Now, it has been found that several neutral salts give different effects on the enzyme in the ascorbate- and non-activated states. This finding is not consistent with the results of Nagashima and Uchiyama," showing that these neutral salts have no effect on the enzyme. This inconsistency is due to the fact that the concentration of salts in their experiments was too low for the non-activated enzyme, and the test with ascorbate-activated myrosinase had not been carried out.

The effect of the salts is obviously due to the anion, not to the cation, because the effects against the ionic strength in the reaction mixture were changed by the valency of the anion, but differences in the cation resulted in no large changes on the curves (Figs. 1 and 2).

In the study of chromatographic behaviors of the enzyme, it was observed ${ }^{51}$ that activities measured by the liberation of sulfate (sulfatase activity) were higher than those measured by the liberation of glucose (thioglucosidase activity) in the presence of $10^{-3} \mathrm{M}$ ascorbate. This phenomenon can be easily explained by the results presented in this paper. The reaction mixture for the test of thioglucosidase activity contained $0.2 \mathrm{~m}$ acetate but did not contain this amount in the case of sulfatase test. So the acetate ion inhibited the enzymatic reactions in the former case. Therefore, the apparent activities of the sulfatase would be higher than those of the thioglucosidase.

The experimental results given in the present paper were represented as sulfatase activities except for the data in Fig. 6 which were obtained as the thioglucosidase activity. In comparison of Figs. 1 and 6 , the general 
shapes of the two curves are similar with the exception of a small difference caused by the presence of $0.2 \mathrm{M}$ acetate ion in the latter reaction mixture. A recent conclusion proposed by several authors, ${ }^{5,7 \sim 91}$ that the myrosinase is not a mixture of thioglucosidase and sulfatase but a single $\beta$-thioglucosidase in its nature, is again supported by this experimental finding.

Cori et al. ${ }^{10}$ illustrated the inhibitory effect of ammonium sulfate and glycerophosphate on muscle glycogen phosphorylase as logarithms of the enzymatic activity units against the square roots of their ionic strength in the reaction mixture and obtained straight lines with negative slopes, but they gave no explanation for their findings. Kistiakowsky et al. ${ }^{11,121}$ found a similar effect of inorganic salts on urease and explained it as the effect of the ionic strength of the solvent on the enzyme according to the Debye-Hückel theory of strong electrolyte solution. Therefore, the results presented in this paper may be explained as the effect of ionic strength of the solvent on the ascorbate-activated myrosinase (Fig. 4). But, for the non-activated myrosinase or for the effects of divalent anions, the above explanation is not applicable. Ettlinger et al. ${ }^{13 !}$ concluded that ascorbate behaved toward

7) M. G. Ettlinger and A. Lundeen, J. Am. Chem. Soc., 78, $4172(1956) ; \mathbf{7 9}, 1764$ (1957).

8) Z. Nagashima and M. Uchiyama, Nippon Nogeikagaku Kaishi, 33, 1144 (1959); Bull. Agr. Chem. Soc. Japan, 23, 555 (1959).

9) P. Calderon, C. S. Pederson and L. R. Mattick, J. Agr. Food Chem., 14, 665 (1966).

10) C.F. Cori, G. T. Cori and A. A. Green, J. Biol. Chem., 151, 39 (1943).

11) G. B. Kistiakowsky, P.C. Mangelsdorf, Jr., A.J. Rosenberg and W. H. R. Shaw, J. Am. Chem. Soc., 74, 5015 (1952).

12) G. B. Kistiakowsky and W. H. R. Shaw, ibid., 75, 2751 (1953).

13) M. G. Ettlinger, G. P. Dateo, Jr., B. W. Harrison, T.J. Mabry and C. P. Thompson, Proc. Natl. Acad. Sci., 47, 1875 (1961). the myrosinase as a reversibly dissociable base, closely connected with the active nucleophilic group. The effect of monovalent anions on the ascorbate-activated enzyme may relate to this behavior of ascorbate.

On the other hand, a similar type of the effect of monovalent anions on various enzymes was discussed recently by Warren et al. ${ }^{14,15}$ They concluded that the organized structure of enzyme protein was disrupted by the anion. Both the $K m$ values of the activated and nonactivated enzyme for the substrate increased with an increment in the concentration of sodium chloride, but the $K m$ value for ascorbate was not affected (Table II). Therefore, accepting the theory of Warren et al., the structure disruption of the myrosinase caused by the monovalent anion would not participate in the effector site for ascorbate but in the substrate site only. Thus, the presence of these two binding sites on the surface of the enzyme protein was confirmed. The difference in sensitivity against anion effect between the activated and non-activated states of the enzyme would be due to the structural difference caused by the binding of ascorbate. Warren et al. ${ }^{14}$ described the different sensitivity of myosin ATPase $\alpha$ and $\beta$ against anion effect and ascribed it to the structural difference of them. Since the mechanisms of the different effects of anions on the myrosinase have, till now, remained obscure, such different effects of monovalent anions on the two states of myrosinase cannot be designated as the densensitization of the effector site of common allosteric enzymes.

14) J. C. Warren, L. Stowring and M. F. Morales, J. Biol. Chem., 241, 309 (1966).

15) J.C. Warren and S.C. Cheatum, Biochem., 5, $1702(1966)$. 